\title{
The Times and the Northern Ireland Conflict
}

\author{
By Zouhaïr Abassi and Nadège Soubiale \\ Université de Reims / Université de Bordeaux III, France
}

Copyright (c) 2006 by Zouhaïr Abassi and Nadège Soubiale. This text may be archived and redistributed both in electronic form and in hard copy, provided that the authors and journal are properly cited and no fee is charged for access.

\begin{abstract}
In societies in conflict the role of the media is supposed to be neutral and to report conflicts fairly and with balanced analyses. By their public debates on conflicts they are also supposed to take part in pacifying societies and in helping to bring peace. Cottle (1997), for instance, explained that even though some findings related to the British media and its reporting of the Northern Ireland conflict were relevant, he argued that they needed revision. Consequently, he proposed new paradigms of media studies. Elliott (1977) and Curtis (1996) showed that the British media concentrated on violence in general and on republican violence in particular. Moreover, they argued that the British media neglected social and political contexts in their reporting of the conflict. The aim of this paper is then to examine some aspects of how the British media cover the Northern Ireland conflict. We studied the coverage of the Northern Ireland conflict by The (London) Times (1990-1995). We used a discourse analysis method to study the paper's discourse structure in its representation of the Northern Ireland conflict.
\end{abstract}

Key Words: Media discourse, British Press, The Times, Reporting Conflicts, Northern Ireland Conflict.

\section{Introduction}

Cottle (1997), in his research review based on most important works that informed the British media and the Northern Ireland conflict, divided all his predecessors' studies into three distinct paradigms. The benefit of his review is then to chart clear fields of studies so as to guide Northern Ireland media readers in their research.

The three paradigms presented by the author are: "international terrorism and propaganda war", "the representation of troubles" and "the state - media relations". His main concern was to demonstrate that some conclusions related to the Northern Ireland conflict needed revision. Thus, he argued that even though some findings were very significant, they could not be considered as

ISSN 1699-311X general rules and applied to all British media coverage of the conflict. According to Cottle, the state-media relations are very complex and subject to frequent changes since they depend on different political contexts and laws (peace process, cease-fires, bans, censorship, recommendations to journalists...). Our goal here is not to rehearse the various "critical" trajectories presented and defended by Cottle but to concentrate on two paradigms closely linked to our study: terrorism, and the representation of troubles. Cottle explains in his conclusion on "terrorism" that orthodoxy represents an important obstacle to understanding the concept of terrorism. He states that: “... From the criticism of the "international terrorism" orthodoxy, a more productive paradigm for the study of the mass media and insurgency emerges [...] "terrorism" on this account, is profoundly a matter of political judgement and interpretation, the key to which is so often the 
claim to political legitimacy. This is not to suggest that all acts of political violence have equal claim for our acceptance, as some clearly do not." (Cottle 1997: 285). However, if Cottle accepts the fact advanced by researchers that acts of state violence are neglected by mass media coverage of conflicts he contested the parallel often made between casualties caused by terrorism and those by governments: “[...] CIA figures for global non-state terrorist killings across the period 1960 to 1980 , for example, amounted to 3,368; a figure in stark contrast to those numerous acts of states terror across the same period...” (Cottle 1997: 283)

In his review Cottle also criticizes the theory developed by Curtis (1984, 1986, 1996). In fact, Curtis asserts that the Republican movement in general and IRA terrorism in particular are stigmatised by the British press and that the British army is presented as almost "above the fray". One of the earliest studies on the troubles in Northern Ireland founded on content analysis and conducted by Elliott (1977) showed that the media were attracted by violence, and particularly by the IRA violence. Terrorism was also depicted as the result of inexplicable asocial acts. Curtis later endorsed these findings. For instance, she contends that "Not only does violence, reported in a nonexplanatory manner, dominate the coverage: it is also presented as if it were the almost exclusive preserve of republicans" (Curtis 1996: 310). Thus the stigmatisation of the IRA is highlighted by Curtis who clearly states: "[...] The IRA violence comes to appear the alpha and omega of the problem and Britain's historical and contemporary responsibility is obscured" (Curtis 1984 cited by Cottle 1997: 286). Cottle concludes then on this theory that if the representation of the Northern Ireland conflict has taken this form it is because many researchers such as Elliot and Curtis have emphasised the routine reliance on army information officers and official sources in general. Approached thus, he points to the fact that: "Curtis appears to entertain a form of media/state closure based on shared institutional commitments to the British establishment" (Cottle 1997: 286). Cottle also questions findings endorsing the fact that news reporting is attracted by violence and tending to omit information on the political process and historical context in order to criminalize and depoliticise the Northern Ireland threat. He argues that the Irish and the Northern Ireland press insisted on the political and social background of the conflict and are less attracted by reporting violence: "Media may in fact provide a good deal more variation in their reporting than has sometimes been conceded, which is not to suggest that this reporting is thereby adequate" (Cottle 1997: 286). However, one can note that Curtis' studies concentrated on the British and not the Irish media.

Finally, with our discourse analysis study we tried to flesh out some skeletal findings derived from Curtis and Cottle's explanations and theories. And as Cottle underlines it: "Given the longevity and seriousness of the Northern Ireland Conflict, the mass communications research bibliography is a little thin" (Cottle 1997: 282). We then studied The Times and its representation of the Northern Ireland conflict.

\section{Representations of conflicts in the press and discourse analysis}

To study representations of armed conflicts in the press, discourse analysis has proven to be both a rich and a rigorous tool. Nevertheless, the French research in this field on political and ideological representations of conflicts in the press often consists of descriptive monographs of corpus elements. Despite the relevance and the richness of such an approach, one couldn't adapt it to the study of a discourse structure. Our main objective by this study was then to highlight not only the content of the The Times' discourse but also its structure.

\section{Statistical methodology in discourse analysis}

Statistical methodology could appear to be an essential tool since, on the one hand, it allows us to define and mark out the lexical and the semantic contents of a given corpus exempt from the researcher's subjectivity (Ghiglione and Blanchet, 1991). On the other hand, thanks to statistical analysis the researcher can have access to the discourse's structural organisation. Thus, for instance, Sergeant (1980), in order to analyse the complete editorials published in 1972 by the national British dailies, used a statistical method called the Factor Analysis of Correspondences. Thanks to this method he brought to the fore discourse thematic classes organised around semantic axes named "factors". This statistical 
method has its origins in the works of Benzecri (1973) on the Analysis of Correspondence.

The statistical tool used here is based on the same principles as the Analysis of Correspondence. The analysis of The Times discourse was achieved thanks to software, which has the name of the method itself: ALCESTE (Analyse Lexicale par Contexte d'un Ensemble de Segments de Texte), designed by a French sociolinguist and engineer, Max Reinert.

Basically, it is a methodology designed for the analysis of literary texts (Reinert, 1990). Nevertheless, it is broadly used in social science research and notably in psychology to analyse interviews and questionnaires (cf. Reinert, 1983, 1986).

Our aim here is not to detail all the statistical analyses in ALCESTE. However, we will just explain, in simple terms, the basic procedure of this software. It consists of a categorization and classification of sets of words related to discourses or texts resulting in a logical discursive structure. This approach is founded on the hypothesis that the discourse's logical structure reflects the logical structure of thoughts. In this way, the discourse structure informs us of the representations associated with a material or symbolic object. Here, we analysed the discourse structure of The Times on the Northern Ireland conflict in order to identify the kind of representations this newspaper developed on the conflict.

\section{The ALCESTE procedure.}

First, the software counts up the most frequent words in the whole corpus (texts, discourses...). Second, it proceeds to the calculation of corpus segments, which are named 'elementary context units' or ecus. An elementary context unit is composed of a regular occurrence of words in the corpus. Words are grouped in a textual segment according to their semantic and temporal proximity in the discourse. Segments or ecus are grouped together to form a 'lexical class'. Each lexical class has its own semantic field. The researcher then has to analyse the meaning of each lexical class. The higher the number of ecus, the more significant is the lexical class.

We studied here the three semantic classes obtained thanks to ALCESTE and presented them in order of importance. The most important class deals with 'terrorism' (836 ecus); the second one deals with the 'Northern Ireland Constitutional Status' (557 ecus); the third one deals with 'The Times and the peace process’ (495 ecus).

\section{The corpus}

We collected all the editorials linked to the Northern Ireland conflict published in The Times from 1990 to 1995 (Abassi, 2001). In that period The Times published 105 editorials on the conflict. The six-year period of study seemed to us to be relevant enough to make grounded conclusions on how the quality paper reported on a current conflict. We analysed this corpus using ALCESTE (the results reported in this article represent only a part of the total results of the work).

\section{Findings and discussion}

Findings showed that The Times was far from neutral in its reporting of the Northern Ireland conflict. On the contrary, by its partial discourse, it turned out to be a part of the Northern Ireland conflict favouring the Protestant/Unionist community to the detriment of the Catholic/Republican/ Nationalist one. By analysing the semantic contents of the lexical classes provided by ALCESTE as far as The Times was concerned, we ought to be able to gain some insight into the category-forming processes on the Republican movement made by the British paper.

The analysis report obtained using ALCESTE showed four classes of discourses, which highlighted the organisation of the structure of The Times' discourse. The discourse of The Times was then evaluated in quantitative terms, which means the number of the categories or classes and the number of elementary context units - the most frequent words in the classes. The nature of the discourse and the representations in The Times of the Northern Ireland conflict could therefore be observed in the lexical contents of the classes obtained by ALCESTE.

\subsection{Analysis and interpretation of The Times discourse}

The analysis of the semantic fields obtained by ALCESTE revealed that each semantic class had a particular thematic axis as far as the Northern Ireland conflict was concerned. The semantic fields showed that during the peace process The Times focused on terrorism in Northern Ireland and on the Republican Party, Sinn Féin. Northern Ireland terrorism was closely if not exclusively linked to the IRA. Sinn Féin was negatively represented and its efforts for 
peace were systematically undermined. The reader could feel as if the conflict was between only two parties: the British government against the Republican Party and its terrorist wing the IRA. What emerged then was that the other parties involved in the conflict, such as the loyalist terror organisations (UDA, UVF or UFF) or Paisley's unionist party DUP, were overshadowed. Also, the moderate parties in Northern Ireland, both nationalist and unionist were neglected in The Times discourse in order to favour a focus on terrorism, especially that of the IRA. This attitude reflected The Times discourse strategy founded on what Cottle (1997) called the "Terrorism Paradigm".

\subsection{Terrorism}

\section{Republican Terrorism}

It is very significant to note that the biggest semantic class in The Times ( 836 ecus $^{1}$ ) dealt exclusively with "terrorism", "acts of terror" and their denunciation. This focus on terrorism was more specifically linked to the three years 1990, 1991 and 1992.

A close examination of the excerpts that constituted the lexical content of the semantic class showed several interdependent dominant aspects in The Times' representation of Northern Ireland terrorism. Almost all the editorials published on terrorism by The Times were closely linked to the IRA. Like the British government's official "line" on Northern Ireland, that of the major newspapers in Britain - The Times included - held the problem to be a sectarian conflict between recalcitrant religious groups kept apart only by the intervention of Britain. The view of Britain was that of a detached, patient, and objective arbiter doing its best to convince two irrational, hate-filled communities to live together in harmony. Constantly undermining these noble efforts was the IRA, portrayed as a gang of mindless criminals and psychopaths bent on destruction. An editorial ${ }^{2}$ in The Times on June $9^{\text {th }} 1992$, entitled KEEPING SECRET, stressed what it considered the main traits of these criminals:

\footnotetext{
${ }^{1}$ ecu: As explained before, an elementary context unit $(e c u)$ is composed of words grouped together to form a segment of a corpus.

${ }^{2}$ All the excerpts of editorials cited in this article are extracted from the corpus of Abassi's PhD (2001)
}

The IRA is a Northern Ireland gangster culture whose activities in Britain are, and should be treated as, those of common criminals. The existing directive to MI5 grants to the IRA the glamour of seeking to "undermine or overthrow democracy"... The IRA is accorded this quasi-political status largely because ministers are fed up with the police and have decided to let MI5 off the leash (...) Terrorists are tribal killers, psychopathic assassins and student anarchists.

The Times also placed the IRA in an "animal category" thus the IRA leave the "human race sphere" to become laboratory rats. The Times summed it up in an editorial entitled "BLAST DAMAGE" (26/04/1993):

...But the Bomb-carriers of the IRA, their minds still maddened to obsession like laboratory rats, will go elsewhere....

With this metaphor The Times suggested the eradication of the IRA or the confinement of its members to laboratory/prison since they are like infected laboratory rats and if they are left free they can propagate damage.

During the first Gulf War, this portrait (of the IRA) was touched up somewhat by the rising concern over "international terrorism"; into the picture were dutifully painted various "links" with other equally anathematised groups or individuals, such as the Palestinian PLO, Hamas, Saddam Hussein and even Hitler and his Nazi party. In an editorial dated (08/02/1991) and entitled "RESISTING TERROR”, The Times report ran:

Many in the West reacted to Saddam's threats by instantly capitulating. They have permitted him to alter their lives and social behaviour, generating a neurosis of doubt as to whether the war is worth fighting, whether beating a distant dictator merits the dislocation, the recession, the fear. Such doubt is soil in which defeatism grows. It is the greatest single threat to victory.... Killers can strike when and how they choose...There will be more such attacks, whether from the IRA or from Saddam Hussein. They are the unavoidable response of an embattled enemy.

World War II was also very present in The Times editorials when it came to analysing the IRA's acts of terror. The following excerpts published in The Times ("BY THEIR DEEDS", 31/07/1990) making analogies between the IRA's attacks and WWII are very illustrative of the daily tone: 
The IRA has shown it will kill anybody who makes a convenient symbolic target, whether soft or hard... It is to assert that there is no resolution of conflicting viewpoints other than through the gun and the bullet... Hardly since the birth of Nazism has Europe seen so blatant a repudiation of democracy in favour of force...

Or when The Times editorialised "BUSINESS AS USUAL" (27/06/1990):

London is approaching the $50^{\text {th }}$ anniversary of the start of the blitz. Before the war it was military dogma that massive aerial bombardment would rapidly and inevitably undermine civilian morale to the point where a government would have to sue for peace. The lesson was in fact the opposite. The experience of the latter part of 1940 - far more testing than anything the IRA could perpetrate - stiffened the popular will for the long haul ahead.

Equally, we can also quote another editorial dated 17/12/1991 and entitled "THE IRA CHRISTMAS CARD” that illustrates the editorial line of The Times on this issue: "The spirit of the 1940's lives on”.

Another analogy often used by The Times in its discourse to defend its struggle against international terrorism is the comparison between on the one side the democratic and legitimate states (Britain/Israel) and on the other side the forces of destruction (IRA /PLO and Hamas). The report in The Times on February $18^{\text {th }}$ 1992, entitled "DEADLY DEBITS”, explained:

In reacting to this violence, both Britain and Israel make great play of their espousal of democracy and the rule of law....

Very significantly, this dualism of conflict opposing democracy to subversion is often coupled with the pronouns WE (British, democratic, and civilised states) and THEY (terrorists, anti-democratic criminals).

This consensus has excluded from debate on Northern Ireland the other view, which might loosely be termed the "republican" analysis. In one form or another, this view is accepted by all non-Unionist political parties in Northern Ireland. It sees the Northern crisis as the offspring of the partition of Ireland (1920), and the conflict as political rather than religious. It holds that as long as Britain maintains a presence in Northern Ireland, the problem will never be solved and argues that in the long term the only hope for permanent peace and stability is some kind of unified state. They differ in that while the establishment parties such as the Nationalist SDLP do not think that violence is justified in achieving the goal they share, the IRA does. We do not propose to discuss this view here.

\section{Loyalist Terrorism}

When The Times dealt with the Protestant paramilitaries, the treatment usually followed lines rather different from those typically applied to the IRA. It is extremely doubtful, for instance, if even attentive readers would be aware of the names of the Protestant paramilitary groups, never being able to discern, from what they read, their actual role in the Northern Ireland violence. The major Protestant paramilitary groups are the Ulster Defence Association (UDA), the Ulster Volunteer Force (UVF) and the Ulster Freedom Fighters (UFF). The UDA, a legal organisation with headquarters in East Belfast, was outlawed by the British government only in 1992. It was formed in 1971. At one time in mid-1972 it claimed about 20,000 members (Rolston \& Miller 1996: 384).

What is noticeable is how little attention was paid to the loyalist campaign of terror during the 1990s, especially when in 1992 loyalist killings outpaced those committed by the IRA. Significantly, in 1991, the loyalist campaign was particularly murderous. O’Brien (1997: 123) explains:

Re-equipped and re-organised loyalist paramilitary groups, the UDA and UVF, in 1991, killed 40, compared to 47 by the IRA. and in 1992, for the first time, loyalist killings outstripped those of the IRA.

Furthermore, O’Brien has noted that on February $5^{\text {th }} 1992$, the UFF killed five Catholic civilians in Belfast and on $30^{\text {th }}$ October 1993, in retaliation for an IRA bomb attack, the UDA, hand in hand with the UFF, killed 8 civilians in Belfast (Shankill) and eight other civilians in a pub (Greysteel) Co. Derry. In 1994, between April and May, the Combined Loyalist Military Command executed nine Catholics in Belfast, Tyrone and Armagh. On June $19^{\text {th }}$ 1994, the UVF, in an operation called "Spray Job", murdered six civilians and injured five in a Catholic pub (Loughinisland) Co. Down where people were watching a World Cup football match between Ireland and Italy.

What is remarkable in this murderous and conflicting context is that The Times was writing about the "Catholic-Protestant" 
conflict, which, the reader was told, the British were preventing from getting out of hand. The consensus The Times adopted here resembled that of the British government. Britain chose to ignore the Protestant paramilitary groups as much as possible, as explained in Rolston and Miller (1996: 387):

Britain's reluctance to tackle the UDA was not based on ignorance of its activities. After all, the police came from the same community as the UDA; contact between them was frequent, information was exchanged, and by the mid-1970s the security forces had a wealth of often detailed data on the organisation. The British view of the Northern crisis as a purely sectarian war initiated by the IRA allowed them to maintain that the Protestant violence was a product of IRA violence so that it was essential to concentrate on stopping the IRA.

All the mass communication techniques used by The Times in this class devoted to terrorism were threefold. Firstly, the "demonisation" of terrorism - the latter is closely linked to the IRA and to the Catholics in Northern Ireland. In its representation of terrorism, The Times focused on the amoral characteristics of its actors (terrorists) and neglected the political and ideological aspects of the Northern Ireland conflict. Secondly, the "decontextualisation" and the "demonisation" of Northern Ireland terrorism with reiterated parallels between the IRA and worldwide dictators such as Saddam Hussein and especially between the IRA and the Nazis. Thirdly, the representation of terrorism is shown by the reiterated use in the daily editorials of the pronouns "we" and "us" as opposed to "they" and "them". Most of the time "we/us" referred to "the British/the Democrats" and the "civilised world", diametrically opposed to "they/them" that referred to "the Northern Ireland IRA members /Catholics/terrorists and murderers".

These aspects of the representation of republican terrorism by the Times remind us of Curtis' theory: they showed what Curtis called the "stigmatisation" of the Republican movement in the British press.

However, other aspects in The Times' discourse partly illustrate Cottle's perspective on mass communication. If Cottle accepts the fact that some media focused on violence, this approach, according to him, cannot then be generalised to all the British media as suggested by some findings in that field. In fact, editorials are quite diverse in their styles or textual strategies, and that is part of the point for suggesting a distinctive voice for The Times. For instance, in the next lexical class on the Northern Ireland constitutional status, we see that the Times deals with a topic other than terrorism.

\subsection{The Northern Ireland Constitutional Status}

Another semantic class (557 ecus) dealt with the constitutional and administrative proposals to solve the Northern Ireland Conflict: The Partition. This political issue was heavily present in The Times editorials in the period between 1992 and 1993, and then reappeared in 1995. The semantic field that constituted this class showed that The Times was hostile to the British Direct Rule of the Province (1972). It considered this ruling system as an economic and political burden on Westminster. The only solution was then a devolved rule to the Province based on establishing mutual consent. For The Times, the major obstacles to a devolved rule in the Province were Articles 2 and 3 of the Irish Constitution, the Republic's claim to Northern Ireland. The Times urged the Irish Government to abrogate them. At the same time, The Times was very hostile to any amendment of the 1920 Government of Ireland Act, which divided Ireland into two parts. It seems that The Times, in its semantic strategy, described the people of Northern Ireland as being neither British nor Irish but "a world apart". That was why The Times defended the idea of devolved rule and even independence for the Province. On this point, the analysis of The Times proved to be right, since Articles 2 and 3 of the Irish Constitution were abrogated in 1998 and devolved rule was established in the six counties (the Good Friday Agreement, April $10^{\text {th }}$ 1998).

In its editorials The Times reviewed the Anglo-Irish efforts and agreements that were meant to help resolve the northern conflict. It revealed then, through its criticism of those Anglo-Irish attempts, its ideology and position on how the Northern Ireland constitutional issue should be addressed.

The Anglo-Irish Agreement (Hillsborough 1985), supposed to bring the protagonists to the negotiating table in Northern Ireland, was a total failure. Hillsborough was rejected by all the unionist parties and the Republican Sinn Féin. Only the nationalist party SDLP 
led by John Hume found it acceptable. The Unionists refused what they considered to be a capitulation, which allowed Dublin to present an Irish dimension on affairs in the north. On the opposite side, Sinn Féin rejected Hillsborough on the grounds that it reenforced the British/Unionist "veto" over the Irish self-determination aspirations. Consequently, the political situation in Northern Ireland was stalled. During the 1990s, Westminster made efforts to get things moving again. The Secretaries of State for Northern Ireland at that period, Mr Brooke (1989-1992), and his successor, Mayhew (1992-1996), attempted to bring all the parties to the negotiating table. What was then known as Brooke's initiative, and carried on by Mayhew, proposed a threefold approach to addressing the Northern Ireland conflict. Firstly, talks between all the protagonists in Northern Ireland. Secondly, North/South talks (Belfast/Dublin), and thirdly, East-West talks involving Dublin and London. In order to entice all the Northern Ireland parties to the negotiating table, Brooke promised the Unionists that they would modify and even nullify Hillsborough if multiparty discussions lead to an agreement. On the other hand, and to push the Republicans to negotiations, he invited Sinn Féin to multiparty talks on the condition that the IRA abandoned violence. Moreover, Brooke declared that Britain had neither economic nor strategic aims in Northern Ireland and that the essential goal of Britain was to bring peace to the Province and help all the conflicting parties to find a multiparty resolution to end violence. Despite all these efforts in search of a constitutional resolution of the conflict, Brooke and his successor Mayhew failed to bring the Northern Ireland communities to the negotiating table and they definitively abandoned "The Three strands Talks". The origins of the failure were then interpreted by The Times as stemming from a lax Westminster facing the eternal refusal of the protagonists to negotiate. Despite the fact that The Times supported a transfer of power to a democratically elected Northern Ireland Assembly, it rebuked the lethargic means used to achieve that purpose. According to The Times, only strong measures could bring the Northern Irish to the negotiating table. The Times suggested that London should issue an ultimatum to all parties in the conflict to discuss and find a compromise or the British State would impose its own resolution upon them. Moreover, The Times considered in its editorials that Direct Rule -instituted since 1972 by Westminster in order to govern the Province- has not been a convenient and durable solution. The Times asserted that Direct Rule had become a hurdle to the emergence of new alternatives in the approach to the conflict resolution. The Times editorialised that because the conflicting parties in Northern Ireland were aware of the fact that if they refuse the compromise, Direct Rule would result. According to The Times, Direct Rule as an alternative remained an obstacle to any progress. Besides, The Times commented that not only was Direct Rule not a solution to the Northern Ireland conflict, but it was a burden to the British economy and it also participated in tarnishing the British image in the eyes of the international communities. In an editorial entitled "THE END OF PATIENCE" (04/07/1991), The Times report ran:

They [the talks] also failed because, for 15 years, all Ulster parties had a greater interest in continued Direct Rule than in any possible alternative. Britain alone had to pay the subsidies and suffer the international ignominy.

What also emerged from The Times analyses on the Northern Ireland constitution issue were "the hurdles" encountered by the Northern Ireland conflict. Apart from the British laxity condemned by The Times, Articles 2 and 3 of the Irish Constitution were equally considered by the newspaper to be major obstacles to any peaceful and democratic resolution of the conflict.

\section{Articles 2 and 3 of the Irish Constitution (1937)}

As mentioned above, the Hillsborough agreement (1985) was rejected by the majority in Northern Ireland: all the unionist parties and by Sinn Féin (Catholics). The Unionists (Protestants) feared the "Irish dimension" granted to Dublin by that agreement. An Irish dimension, which, however, was but a consultative one with no legal power. The Unionists then refused any discussion because of Hillsborough and its Irish dimension. In order to defuse the situation The Times proposed that the Irish Republic abrogated its Articles 2 and 3, which stipulated that Northern Ireland and its territorial seas were part of the Irish Republic. According to The 
Times, once those articles were nullified or amended discussions on the Northern Ireland conflict would be more balanced and all the Unionists would agree then to talk with Nationalists and Sinn Féin. In an editorial entitled “IRELAND EXPECTS” (06/05/1992), The Times asserted:

None of the parties is now against power sharing in principle, even if they cannot agree on the details. What mainly divides them is the "Irish Dimension" the form of involvement of the Irish government in Northern Ireland's affairs. A contribution to the present constructive mood that Dublin obviously ought to make is an adjustment of the claim in its Constitution to govern the whole of Ireland. An aim is legitimate, a "claim is not".

This is why, for instance, The Times was delighted by the Irish Foreign Minster's (Dick Spring) announcement when he declared in October 1993 that he was ready to review Articles 2 and 3 of the Irish Constitution. It then published an editorial entitled "WHOSE PEACE?” (30/10/1993) and commented:

This week, Dick Spring, the deputy prime minister and foreign minister, reopened the vexed question of Articles 2 and 3, which assert the Republic's constitutional claim to the province and have long been a stumblingblock to productive negotiation with the Loyalist community. The Irish government has also firmly acknowledged "once and for all the freedom of Unionists to withhold their consent" to change. This recognition, appears to mark a new realism and clarity in some areas of Dublin's diplomatic thinking.

But when one year later the Irish Prime Minister, Mr Reynolds in an interview in The Irish Times (June $21^{\text {st }}$ 1994), proposed abrogating Articles 2 and 3 on the condition that Dublin would have an executive role in Northern Ireland's affairs, The Times then condemned that declaration and simply demanded the abrogation of the two Articles with no compensation at all, neither to Dublin nor to the Nationalists (SDLP) and the Republicans (Sinn Féin) in Northern Ireland. The Times firmly opposed the political perspective suggested by the Irish Prime Minister and refuted any kind of compensation in return for the abrogation of Articles 2 and 3. For instance, it rejected the idea of amending the (British) Government of Ireland Act (1920), which stipulates that Northern Ireland is part of the United
Kingdom. The day after Reynold's revelation, The Times headlined "ARTICLES OF POOR FAITH: Britain Should Reject the Deal Proposed by the Taoiseach" (22/06/1994). Its report ran:

In the interview, Mr Reynolds demanded a cross-border authority in return for rescinding Articles 2 and 3 of the 1937 Irish Constitution... Yesterday the Taoiseach came closer to spelling out the conditions, which the South would try to exact from the British Government and the Unionist community. He expected "institutional links between North and South" which - crucially - would have "executive powers".... It would involve major amendment of the 1920 Government of Ireland Act. This proposed bargain should be rejected by British Ministers.

To sum up, The Times quite simply demanded the repeal of Articles 2 and 3 while defending the Government of Ireland Act. By its argumentation The Times was then defending the British and the Unionists' interests. It adopted similar positions to those of the Unionists and Westminster when it came to editorialise on the constitutional status of Northern Ireland. The Unionists and the British government banned and abhorred the two Irish Articles, as did The Times. For instance, the newspaper has always asserted solemnly that those two Irish Articles were shameful, scandalous, anachronistic and not worthy of European noble values and nations. In an editorial entitled "TROUBLES AHEAD" (23/08/1994) The Times editorialised:

Articles 2 and 3 of the Irish Constitution... Are an outrageous anachronism of which any modern European state should be ashamed.

We can also quote The Times, which also confirmed in "ARTICLES OF POOR FAITH" (22/06/1994) that:

Articles 2 and 3, which were recently declared a "constitutional imperative" by the Irish Court, are an outrageous anachronism rather than a legitimate bargaining chip. For Ireland to claim territorial rights over part of another European Union member state also makes a mockery of its high-minded aspirations as a European nation.

Other editorials conveyed the same ideology upon the constitutional status of Northern Ireland but what is remarkable and striking is the similarity between the discourse 
developed by The Times and that of the Unionists and their sympathisers. For instance, Mr Molyneaux, the UUP's leader at the time, declared (Molyneaux's declarations published in The Irish Times on October $29^{\text {th }}$ 1991 and cited in McGarry \& O’Leary 1995: 95):

Eire's claim to Lebensraum - is the equivalent to Hitler's claim over Czechoslovakia.

As we have seen above, this analogy with Hitler was also used by The Times when it compared the Republicans with the Nazis. Mr Paisley, the leader of the unionist party DUP has the same analysis (cited in McGarry \& O’Leary 1995: 99):

The Government of the Republic of Ireland claims illegally the territory of Northern Ireland, which is part of the United Kingdom, and therefore that obstacle must be removed before a new and good relationship can exist with the Irish Republic.

\subsection{The Times and the peace process}

Another semantic class (495 ecus) dealt with the negotiations that took place between the British Government and Sinn Féin in order to convince the IRA to abandon political violence. It was a dominant theme in The Times editorials during 1994-1995. The Times showed here its hostility very specifically to the Republican Party, Sinn Féin, and its terrorist wing: the IRA. In its discourse, it excluded Sinn Féin from any negotiations. The IRA declared on August $31^{\text {st }} 1994$, a "complete cessation" of its activities, which means implicitly that it could resume terrorist acts. In short the IRA declaration did not equal a permanent abandonment of violence. Consequently, The Times rejected the IRA's proposition on the grounds that it was not a "permanent cease-fire" and demanded at the same time that the IRA surrender its arms.

At the same time the "Protestant" Loyalist terror was roughly present in The Times discourse, which means that it was somehow extirpated. This onesided representation makes the reader feel that the only "culprits" in the conflict are Sinn Féin/IRA. Indirectly, the other parties, notably the Unionists, were presented as "innocent" since they were not castigated as much as the Republicans (Sinn Féin/IRA). Moreover, and even though many positive steps were achieved during the Northern Ireland peace process, The Times discourse focused on the negative side of the conflict. The reasons behind The Times' preference for this discourse remain ambiguous and perhaps ideologically motivated.

\section{The representation of Sinn Féin and its political leaders}

Generally speaking, the Republican Party is represented by The Times as the principal hurdle to any peace process in Northern Ireland. The reasons given by The Times are the irredentism of Sinn Féin and its support for terrorism. All the arguments of The Times were founded on this principle, hence its consistent anti-republicanism. Republicans were heavily included in The Times (26 editorials out of 27 linked to terrorism were about Sinn Féin/IRA). And at the same time they were ideologically excluded. In its representation of Sinn Féin, the newspaper opted for a discourse of exclusion, which is founded on the terrorist past of its leaders, Gerry Adams and his Deputy Martin McGuinness. The Times maintained its representation even after the IRA's cease-fires (August 1994 and July 1997), since these two cease-fires did not mean a definitive abandonment of violence.

\section{McGuinness: A terrorist proud of his criminal acts}

During the peace process, every time a Republican delegation met or was scheduled to meet with British officials, the Sinn Féin negotiators' efforts were systematically questioned by The Times discourse. The criminal and the prison past of its members were recalled. For instance, when on December $9^{\text {th }}$ 1994, British officials met with Sinn Féin members in Belfast, the following day The Times reacted immediately by publishing an editorial with the evocative title "THE ROAD TO STORMONT: Never Forget How Sinn Féin Reached The Peace Table" (10/12/1994). The editorial about the delegation led by McGuinness is unequivocal:

The party is taken seriously by the British
Government because it is the political wing of
the most murderous and well-organised
terrorist group in the world. Of the five
republican delegates yesterday, three have
served prison sentences for the IRA offences...

One can notice here the abusive use of the superlative "most"... in the World. Certainly, no one could justify the terrorist acts of the IRA, but there are other terrorist groups, which are more powerful than the IRA. Moreover, The Times depicted Sinn Féin as a small unpopular 
Marxist party with no electoral support. It only achieved notoriety for terrorist acts.

Since the meeting of December $9^{\text {th }} 1994$ between British officials and a Republican delegation, McGuinness and his comrades have been targeted by The Times' acerbic criticism. They were systematically presented as "ex-cons, ex-criminals, ex-terrorists proud of their criminal organisation", even when they were secondary themes in The Times editorials. This kind of phrases became a systematic reflex in The Times discourse when it came to dealing with the republican leaders. Every time the name of McGuinness was mentioned in the editorials of The Times it was accompanied by a summary of the Sinn Féin deputy leader's past. The Times acted as if the personality of McGuinness needed "explanatory instructions" to help its readership understand how the Sinn Féin leaders "functioned" and would "function" in the future. The phrases used to depict McGuinness - elected Minister for Education to the Northern Ireland Assembly (1998) - were hammered out and seemed to act as a slogan. They were meant to give a "condensed summary" of what a republican leader could be. Thus, what a reader could recall once he had finished reading an editorial from The Times are the following phrases: "Republicans are ex-prisoners and terrorists proud of their criminal acts."

For instance, we can quote here an editorial that illustrates this discursive strategy used by The Times: "THE PIKE IN THE THATCH. Time for a Symbolic Act of Good Faith by Sinn Féin” (26/04/1995). It ran:

The delegation, which is expected to meet Michael Ancram, may include three people convicted of IRA offences. It is likely to be headed by Martin McGuinness, a senior member of Sinn Féin who has been jailed in the South in 1973 for his membership. At the time he said he was very, very proud of his association with that murderous organisation.

Or this excerpt taken from "HISTORIC HANDSHAKE” editorial (11/05/1995):

(...) Three of yesterday's Republican delegation have been convicted of IRA offences. Its leader, Martin McGuinness, has twice been found guilty of IRA membership and told a Dublin court in 1973 (...) He was "very, very proud" of his association with that criminal organisation.
These excerpts illustrate the negative representation of Sinn Féin in The Times. The message of The Times emphasizes the terrorist acts of Republicans in order to marginalize their political claims and finally exclude them from the negotiating table. This kind of social representation model adopted by The Times has probably a more global aim, which is to depoliticise the Republicans' political claims. In fact, nothing was said about McGuinness's ideology nor the political line of the party he represents. This political representation of the Republican movement was not only limited to McGuinness; the Sinn Féin President, Gerry Adams, was represented in the same way.

\section{Gerry Adams: A hypocritical leader}

Once again, as it did with McGuinness, The Times recalled the criminal essence of the Republican leader. Though he committed himself to talks, Gerry Adams remained, according to The Times, a terrorist with a "hidden agenda", who behaved deceitfully. He had all the appearances of a peaceful negotiator but behind the scenes he supported the IRA. He was presented as a man of political intrigues and accused of playing a double game in the peace process. In short a man who cannot be trusted at all. The Times editorialised “TIME TO DECLARE” (02/02/1994):

(...) The Armalite-and-ballot-box strategy which Mr Adams has master-minded (...) Mr Adams has already promised Americans that Sinn Féin is the party of peace... Hours after he made his hypocritical pledge to camera, the IRA launched a mortar against troops in $\mathrm{CO}$ Down.

Stylistically speaking, The Times used an allusion technique. It very often referred indirectly to Gerry Adams as masterminding terrorist attacks. For instance, in "CEASE THE HYPOCRISY” (01/04/1994), it used a narrative style that easily allowed the reader to infer that there were links between Gerry Adams, Bomb attacks and the IRA:

While he (Gerry Adams) and his colleagues have dithered and obfuscated on every platform available to them, the terrorists have carried on their work undeterred.

Certainly one could neither neglect the existing links between Sinn Féin and the IRA nor the ambiguity of the Republicans at the beginning of the 1990s peace process nor McGuinness's prison past. However, one could be surprised at the fact that The Times sometimes focused its analyses on terrorist 
aspects while ignoring the efforts and progress made by Dublin, London and Northern Ireland parties who committed themselves to the peace process. Did The Times change its negative representation strategy of Sinn Féin after the IRA's cease-fire? Consequently, we will examine the representation of the Republican Party before and after the IRA's cease-fire.

\section{The Times and the representation of the Republican Party before and after the IRA's cease-fire}

When they signed the Anglo-Irish Declaration (on December $15^{\text {th }}$ 1993), the British and Irish plenipotentiaries hoped for a permanent end to the violence. Their main aim was to create a peaceful and democratic framework in order to allow talks between parties in Northern Ireland. The Times then focused upon the IRA's arms and Sinn Féin. Though the prevailing discourse of The Times was initially in favour of a permanent IRA cease-fire as a precondition for Sinn Féin joining the peace talks, the paper changed its strategy. Its initial discourse grew quickly into a rejection of Sinn Féin/IRA from the negotiating table on the grounds that they were imbued with murderous cultures and consequently it was impossible for them to abandon terror acts. For instance, in its editorial (11/01/1994) entitled “TIME TO CLARIFY. Sinn Féin Procrastination Should be Tolerated No Longer”, The Times affirmed that Sinn Féin was a hypocritical party with a double discourse:

In fact, the likelihood that Sinn Féin will renounce violence and join the peace process is diminishing daily... The vacillation of republican political leaders since the Declaration has merely betrayed their reluctance to abandon the familiar "ballot and bullet".

The Sinn Féin representation that emerged from The Times editorials was that of a "zigzagging" party, which played at being politically sincere. In short, it is an untrustworthy organisation. The Times then explained in its editorial "THE IRA ANSWER" (10/03/1994):

Since John Major and Albert Reynolds, the Taoiseach, signed their Declaration in December, Sinn Féin has sought to nurture an atmosphere of suspense and uncertainty.

Or in its editorial "VERY MUCH DEAD" (26/07/1994/):

The Declaration signed in December by John Major and Albert Reynolds reflected the belief that Sinn Féin was ready to renounce violence in return for a place at the negotiating table. Sinn Féin has exploited this misconception mercifully, hinting that it wishes to join the peace process without accepting the clear preconditions set out in the Declaration... The British and Irish governments were mistaken to woo the party in the first place.

Stylistically speaking, The Times used almost the same words to depict Sinn Féin, their leaders and the IRA. This shared semantic field seemed to highlight an ideological fusion and cohesion of all the republican groups, which were considered as a monolithic group at the service of terror with no hope of change.

Even though the Anglo-Irish Declaration (1993) invited all the Northern Ireland parties and organisations linked to terrorism to abandon violence, The Times presented it as though it were exclusively addressed to Sinn Féin/IRA. The Times questioned at the same time the role of the Declaration on the "Republican men of terror" to abandon violence. The Times urged the British Prime Minister to give up the Declaration and change his strategy in the peace process. It editorialised “THE IRA ANSWER” (10/03/1994):

The sooner the Prime Minister ceases to delude himself the better. The Declaration has failed in its purposes... Dublin must remember its promises to take appropriate action - meaning security measures - if the initiative failed... The Republican gauntlet has been thrown down at Mr Major's feet. Having invested so much capital in a failed peace process, he must show he is willing to invest energy in a quite different approach.

Dublin and London were then warned that only a security approach to the conflict during this peace process would be reliable and efficient against the IRA's terror. The Times rejected the idea that the IRA would be seduced by the Declaration and would renounce violence. This was the statement of The Times on Sinn Féin/IRA before the republican cease-fire (August 31 $1^{\text {st }}$ 1994). So what about the representation of Sinn Féin/IRA by The Times after the cease-fire? Visibly, The Times did not significantly change its attitudes towards the Republicans. Before the IRA's cease-fire, it suspected the intentions of Sinn Féin/IRA. Consequently, it was impossible for the IRA to make a peaceful move and announce a cease-fire. When the IRA declared its cease-fire, The Times seemed to be 
surprised and adopted a radical stance arguing that a cease-fire was not enough and that the IRA should disarm. This shift reflected the Unionists' point of view that demanded the IRA's disarmament as a precondition for Sinn Féin joining the negotiating table. John Major, to secure his majority in the British Parliament, supported the unionist exigencies. The IRA's disarmament quickly became a central question among the British officials and the Unionists. It was because of that disarmament issue that the Northern Ireland Assembly (created after the Good Friday Agreement 1998) was blocked for a long time and then suspended in October 2002. However, in the Anglo-Irish Declaration (1993), by which London and Dublin expected an end to violence, there was neither explicit nor implicit allusion to disarmament of any republican or loyalist terrorist organisation. The signatories of the Declaration asked for an end to the violence in order to set up a propitiated framework for a peace process and discussion on the Northern Ireland conflict.

The day after the IRA's cease-fire the discourse of The Times became very demanding. On September $1^{\text {st }} 1994$, in an editorial entitled "AFTER THE CEASE-FIRE: Hopes and Perils About Ulster", The Times argued:

(...) A priority in the weeks ahead must be the establishment of an arms dump where paramilitaries can deposit their weapons and explosives to be destroyed, without fear that they will be used as evidence in court.

The radicalisation of The Times vis-à-vis the Republican paramilitaries after their ceasefire went hand in hand with the daily ideology. In fact, The Times has always abhorred any participation of Sinn Féin in the peace process. Also, it advised the British government not to negotiate with Sinn Féin. The Times stand on Sinn Féin/IRA reflected unionist positions. The Unionists rejected any idea of negotiating or governing with a terrorist party.

The Times seemed then to make use of a subtle ideological manoeuvre implicitly supporting the unionist standpoint and at the same time ideologically excluding Sinn Féin from the political arena. The Times highlighted the republican terrorist culture, present and past, in order to bolster its positions. It argued that the long republican terrorist past was a huge obstacle to changes in IRA/Sinn Féin ideology since they could not abandon so quickly a terrorism culture they had been imbued with for many generations. In these conditions, and to resolve this dilemma, The Times advised that the IRA should deposit their arms in order to be destroyed.

It is then not very surprising that a few months after The Times recommendations on "the necessity of disarming the IRA" that British officials became very demanding and adopted the same viewpoint defended by The Times.

Thus, during talks with Sinn Féin members (09/12/1994), Deutsch (1998: 111) mentions that:

British officials met solemnly Sinn Féin members but they required the disarmament of the IRA as a precondition to any participation of the Republicans in discussions.

It is not sure that The Times has influenced British officials as far as the disarmament issue is concerned, but the coincidence of interests between the paper and the British politicians is a remarkable one.

Eventually, as above, the disarmament issue raised by The Times reflected the Unionists' position. Both The Times and the Unionists adopted the same discourse based on the fact that the IRA was not able to give up violence and subsequently Sinn Féin should be excluded from the peace negotiations. On this point, Deutsch (1998: 22) argues that disarmament:

(...) became a means to delay multiparty negotiations and on this issue London followed the unionist example.

\section{Cease-fire or not the pressure is on Sinn Féin/IRA}

The Times stuck to its guns, defending the principal of "disarmament" because this was central to the peace process. In fact, The Times, politicians and analysts knew that at least at the beginning of a peace process and after a fresh cease-fire it was impossible for the IRA to surrender its arms. Knowing this, one could think that The Times used the disarmament issue as a means of putting pressure on Sinn Féin and excluding it from negotiations. In this way, and despite the fact that both the IRA and the Combined Loyalist Military Command were linked to terrorism, The Times focused on republican terrorism. Through its editorials, The Times put the IRA in the dock and questioned the seriousness of their cease-fire. In this way it could create a suspicious atmosphere by its discourse and arouse fears 
among unionists in Northern Ireland. Also, Sinn Féin's political intentions were suspected, which did not help confidence in the Northern Ireland peace process. The Times argued, systematically, that Sinn Féin/IRA were hypocritical individuals who had "their hidden agenda" concealing their bad intentions behind cease-fire declarations. The paper used facts, statistics and the IRA's past and present to anticipate and make suppositions on the peace process. For instance, The Times recalled how the IRA in 1975 disrupted its cease-fire and even increased its attacks. It editorialised “PEACE IN THEIR TIME” (22/08/1994):

The IRA has often played - or hinted at playing - the cease-fire card. The so-called truce of 1975 was nothing of the kind: 247 people were killed and 2663 injured during the year. Christmas cease-fires have become a cynical institution ending in predictable bloodshed. The 72-hour cease-fire in April achieved nothing but more publicity for Sinn Féin.

Moreover, The Times reminded us of the fact that that the IRA's cease-fire on August $31^{\text {st }} 1994$ was not enough since it was not a "permanent" cessation of violence but only a "complete" cessation as the IRA declared it. The Times then conducted a campaign for the disarmament of all Northern Ireland terrorist organisations on the grounds that it was the only guarantee to secure a permanent cessation of terrorism. However the first targets were the republican terrorists. The following editorial titles illustrate that position: The "SEMTEX FOR LASTING PEACE: The IRA Must Surrender its Arms" (22/10//1994); "ROAD TO DISARMAMENT” (09/03/1995); “A PAUSE IN THE PEACE” (07/09/1995/); “AFTER THE VISIT” (30/11/1995); “IRA DISARMAMENT” (15/08/ 1995); "ADAMS THE KEY: Irish Republicans Must Open the Next Door to Peace" (15/08/1995). All the previous editorials were subsequent to the IRA's cease-fire.

With hindsight, one could realise that the idea of disarming the IRA was a strategy meant to exclude Sinn Féin. Disarmament was not part of the peace process exigencies. In fact, according to Deutsch (1998: 22), the principle of disarmament emerged from the pressure made by Unionists on Major who needed the Unionist MPs' support to secure his majority in the Parliament:

Undoubtedly the British had made important progress in their analyses as far as
Republicans were concerned... But they surely were not able to predict the extent of Republican resistance to disarmament. It seemed that the principle of disarmament had never been put on the table during negotiations prior to the Anglo-Irish Declaration (1993). G. Adams and A. Reynolds, both of them affirmed it clearly and officially on several occasions.

O’Brien (1997: 144) confirmed the same analysis:

From the outset the Unionists had sought the complete disarmament and disbandment of the IRA before they would enter negotiations involving Sinn Féin. Soon during the exploratory talks with Sinn Féin, the British side began raising the question of decommissioning the IRA arms in advance of talks.

One could think that The Times discourse, like Sinn Féin, their leaders and the IRA was not a random one, but seemed to be a deliberate message to undermine any support for Sinn Féin. This judgement is founded on the nature of the text we have selected to study: editorials. In a newspaper, this kind of text is very demanding. It requires at least two meetings per day to decide on the subject of a leader, its title, and its contents; so the political and social representations of the Republicans are not due to chance. It is a well-organised discourse meant to reach public opinion, politicians and decision makers in a debate on society. Moreover, The Times is aware of the power of language and significantly asserted it in an editorial entitled "WARFARE WITH WORDS” (20/09/1990). Its comment ran:

Maintaining the "no war" policy (and its language) is crucial to victory over IRA terrorism and to normalising life in Northern Ireland. It is crucial to the moral supremacy of the security forces...But the continued criminalisation of the activities of the IRA is essential to British policy.

\section{Conclusion}

The study of the semantic classes in The Times provided by ALCESTE shows that the discourse of The Times was ideologically oriented and polarised. When it dealt either with terrorism or agreements such as the Anglo-Irish Declaration (1993) or with the cease-fires announced by the IRA and the Loyalist Military Combined Command and their disarmament, The Times focused on one category of protagonists: The Republicans. 
With this kind of political representation of the Northern Ireland conflict the reader has the impression that Sinn Féin/IRA were the only conflictive actor in the province. For instance, The Times was careful not to stress loyalist terrorism and its actors and supporters such as the Ulster Democratic Party (UDP) and the Progressive Unionist Party (PUP) which are two political formations linked with terrorist groups: The Ulster Volunteer Force (UVF), The Ulster Freedom Fighters (UFF) and The Ulster Democratic Association (UDA). None of these loyalist organisations was significantly dealt with in The Times editorials.

Also, The Times argumentation on the conflict was founded on the hypothesis that Sinn Féin would never accept democratic principles. The Times bolstered its political viewpoint by systematically referring to the IRA's terrorist attacks while it avoided stressing loyalist terrorism which perpetrated spectacular attacks such as a loyalist rocket attack against the Sinn Féin offices in Belfast (29/03/1994), perpetrated by the UFF.

Finally, important nationalist and unionist parties were neglected in The Times' discourse. Peaceful parties such as the SDLP (nationalist), the UUP (Ulster Unionist Party) were relegated to a position of no importance. Does this mean that the British conservative press tends to focus in their media coverage of the Northern Ireland conflict on its symptoms (violence/ terrorism), while neglecting political analyses and peaceful efforts made by democratic and peaceful parties who represent the majority in the Province? We can argue that The Times expressed its deep political convictions on different points as far as the conflict was concerned. It clearly supported what it considered to be a sensible reflection on terrorism, on the peace process and on the constitutional status of the Province. It is not then a mere reporter of the Northern Ireland conflict without any ideology or subservient to the British government. On the contrary The Times criticised and even advised the British decision makers on the conflict every time it judged it necessary to do so. Thus, the editorials studied here illuminate a discourse of institutional power in the sense that emerges from, and in turn helps construct, The Times' claimed authority. And as Fowler (1991: 2089) put it: "That discourse is always representation from a certain point of view. This theory of structured representation is valid for any discourse: I am not saying that newspapers are particularly 'biased' (even though most have a political axe to grind); all texts, e.g. physics textbooks, do-it-yourself manuals...children's books...are discursive constructions of some world. What is distinctive about editorials is not that they offer values and beliefs, but that they employ textual strategies which foreground the speech act of offering values and beliefs.”

\section{Works Cited}

Abassi, Zouhaïr. 2001. Le conflit nord-irlandais à travers la presse britannique de qualité: le cas du Times et du Guardian (1990-1995). Doctorat Nouveau Régime (PhD). Université Toulouse le Mirail. France.

Benzecri, Jean-Pierre. 1973. L'Analyse des Données. Paris: Dunod.

Cottle, Simon. 1997. "Reporting the Troubles in Northern Ireland: Paradigms and Media Propaganda”, Critical Studies in Mass Communications, 14, 282-296.

Curtis, Liz. 1984. Ireland the propaganda war: The British media and the battle for hearts and minds. London: Pluto Press.

1986. "British Broadcasting and Ireland, Curran et al. (Eds.), Bending reality. London: Pluto Press, pp.58-67.

1996. "Reporting Republican Violence”, B. Rolston \& D. Miller (Eds.), War and Words. Belfast: Beyond the Pale Publications.

Deutsch, Richard. 1998. Le sentier de la paix, l'accord anglo-irlandais de 1998. Paris: Terres de Brume Éditions.

Elliott, Patrick. 1977. "Reporting Northern Ireland: A study of news in Great Britain, Northern Ireland and the Republic of Ireland" UNESCO (Eds.), Ethnicity and the media. Paris: UNESCO, pp.263-376.

Fowler, Roger. 1991. Language in the News Discourse and Ideology in the Press. London: Rutledge.

Ghiglione, Rodolphe et Blanchet, Alain. 1991. Analyse de Contenu et Contenus de l'Analyse. Paris: Dunod.

McGarry, John and O’Leary, Brendan. 1995. Explaining Northern Ireland. Oxford and Cambridge: Blackwell.

O’Brien, Brendan. 1997. A Pocket History of the IRA from 1916 onwards. Dublin: The O’Brien Press.

Reinert, Max. 1983. "Une Méthode de Classification Descendante Hiérarchique: application à l'analyse lexicale par contexte", 
Cahiers de l'Analyse des Données, no. 3,187198.

1986. Un Logiciel d'Analyse Lexicale [ALCESTE], Cahiers de l'Analyse des Données, 4, 471-484.

1990. ALCESTE: une méthodologie d'analyse des données textuelles et une Application: Aurélia de Gérard de Nerval,
Bulletin de Méthodologie Sociologique, 26, 24-54.

Rolston, Bill and Miller, David. 1996. War and Words: The Northern Ireland Media Reader. Belfast: Beyond the Pale Publications.

Sergeant, Jean-Claude. 1980. Les Éditoriaux des Quotidiens Nationaux Britanniques. Doctorat d’État présenté à la Sorbonne Nouvelle, Paris. 